\title{
BUSINESS DESIGN MANAGEMENT EDUCATION: CASE INSIGHTS*
}

\author{
Sharm Manwani ${ }^{1} \&$ Mark Lancelott ${ }^{2}$
}

UDC/UDK: 658.5:005.22:37

JEL classification / JEL klasifikacija: M12, N3

DOI: https://dpo.org/10.22598/pi-be/2018.12.2.71

Preliminary communication / Prethodno priopćenje

Received / Primljeno: September 3, 2018 / 3. rujna 2018.

Accepted for publishing / Prihvaćeno za tisak: November 30, 2018 / 30. studenoga 2018.

\section{Summary}

Both academic and professional researchers have identified significant challenges in moving from business strategy to operational execution. A key tool to close this gap is business design, with both entrepreneurial start-ups and large enterprises desiring innovation seeking to design new business and operating models. The big gap between strategy and execution highlights a need for management education that is both rigorous and relevant. Academic theories are a key component but need to be combined with practical leadership insights.

According to researchers, business schools face significant strategic challenges in delivering management education. The pedagogical design principles with programs for experienced professionals and managers are different to those of pre-experience students. There is a need for demand-driven offerings, particularly in custom education yet academic integrity must be safeguarded to retain credibility. This represents a key opportunity for business schools, particularly if they can work in partnership with organizations seeking to enhance their business design capability.

To-date, there are few published examples of successful business design custom education programs. This paper provides a longitudinal review of one such program run over more than 5 years, covering more than 10 cohorts of $250+$ partners and senior consultants from an international innovation and transformation consultancy. The case study explores

\footnotetext{
The paper was presented at the 3rd International Conference „Business \& Entrepreneurial Economics -BEE2018” which was held in Šibenik from 30 May to 2 June 2018 (www.bee-conference.com)

1 Sharm Manwani, Ph.D., Professor, Henley Business School, University of Reading, United Kingdom, E-mail: sharm.manwani@henley.ac.uk

2 Mark Lancelott, PA Consulting Group, United Kingdom, E-mail: mark.lancelott@paconsulting.com
} 
the initiation, design, execution and results of the program from the perspectives of the customer organization and the supplying business school.

The program deliverables have led to successful outcomes for both the consultancy and their clients. This result was predicated on a strong partnership between the organization and the business school, achieved through an evolutionary delivery. Insights and recommendations were generated that cover the leadership, design and evaluation of the program - which the authors believe have wider transferability, both for research and education purposes.

Key words: business strategy, operational execution, business design, management education.

\section{INTRODUCTION}

Researchers have identified significant challenges in moving from business strategy to operational execution. Wiita and Leonard (2017) propose several responses including 'shaping the future' and 'translate strategy into everyday processes and capabilities'. A key tool to close this gap is business design which is used by all types of enterprises to innovate new business and operating models.

The continuing large gap between strategy and execution highlights a need for management education that is both rigorous (in line with theory) and relevant (for leaders and experts). Yet, business schools face significant strategic challenges in delivering management education according to Lorange (2005). Rather than just acquiring knowledge, business professionals are more concerned with how they can apply the learning in complex management settings. The findings of Bernon and Mena (2013) show that experiential learning, project work with faculty engagement, and post-course project activity aid these types of practitioners.

Lorange (2005) also notes there is a drive towards demand-driven offerings, for example in custom education rather than commodity offerings. Creating such programs therefore represents a key opportunity area for business schools. The challenge is that it is difficult for business schools to acquire the capabilities to create and run these high engagement programs. One innovative way to address the difficulty is to work in partnership with leading organizations willing to invest their time and expertise as well as their money to develop these professionals.

To-date, there is a dearth of published examples of successful partnership business design custom education programs. This paper provides a longitudinal review of one such program developed by an international business school developed and run over several years with and for an international innovation and transformation consultancy. 


\section{METHODOLOGY}

Given the limited research into custom education offerings jointly created by business schools and customer organizations, an exploratory methodology was selected for the research. This paper provides a longitudinal review of a custom qualification program successfully run more than ten times for a period of more than five years. The goal of the review is to generate insights from the program lifecycle of set-up, approach and outputs that cover the leadership, design and evaluation of this type of program.

The customer organization, PA Consulting Group (PA) is a global innovation and transformation consulting company. It is an employee part-owned firm, with over 2500 experts and has its own data and technology science hubs working on multi-sector breakthrough innovation programs.

In line with the goal of creating a successful practice this requires developing market-demanded capability. PA specifically wanted a program that was both tailored and relevant for its experienced professionals and at the same time rigorous - to be demonstrated through a business school certification. They decided to co-develop this with Henley Business School (HBS) which is international and triple-accredited with a long tradition of management education and postgraduate qualifications including masters and doctoral programs.

The program, started in 2012 aimed to integrate PA's business and IT transformation approaches to better design and deliver transformation for clients. The program set out to provide PA partners and senior consultants with a deeper alignment of business and technology design, rather than just implementing specific technologies or business transformation approaches. This demand is consistent with the research findings of Vo et al (2006) who linked the high incidence of IS project failure to IS professionals overly focusing on acquiring technical skills. To-date, in early 2018, over 250 participants have successfully completed the program and it is now on its $12^{\text {th }}$ cohort.

The authors of this paper are the HBS program director and the current PA owner of the program, a director in PA's Business Design practice who have both experienced and influenced the longitudinal development of the program. This contribution provides a richness of understanding of the case - and to address objectivity, secondary sources of information have been used including documentation created for the program and an approved case study.

The longitudinal review sets out to answer the following questions.

1. What were the goals and the selection process for the program?

2. What were the stakeholder demands of PA and HBS?

3. What capabilities did HBS, PA and other parties bring to the program?

4. What were the outputs and benefits of the program?

5. What lessons have been learned?

The points 1-4 are covered in Results and point 5 is covered in Conclusions. 


\section{RESULTS}

The background to the case including the goals of the customer organisation is described first. This is followed by the demands of the program stakeholders and capabilities, with the final section reviewing the program outputs and outcomes.

\subsection{Case Organisation Goals and Program Setup}

PA sees business design expertise playing a critical role in helping organisations translate strategy into execution. Forces such as consumerisation, mobile, social networking and big data are having a major impact on society and economic ecosystems.

In response, businesses need to become more agile and reconfigurable. They need to define, design, and deliver changes effectively. PA was committed to building its business design expertise while strengthening its image as an attractive employer brand both internally and externally. Hence PA set out to enhance the capability of its consultants via a professional development program. To achieve this goal PA sought to bring together the best mix of internal and external expertise.

PA selected HBS to design a unique, jointly-developed and delivered educational program leading to a HBS certificate of completion. A senior partner in PA explained the company's approach to its professional development, 'PA wanted academic partners who shared a similar vision in supporting clients to bridge the gap between their market and their ability to continuously re-invent their business to meet those market needs. Through multiple cohorts the Henley team has helped to build our business design capability.'

\subsection{Stakeholder Demands and Capabilities}

The partnership approach to a custom professional education program required the engagement of many different stakeholders. In partnering with HBS to develop and run the course, PA committed three members of its management committee to lead the design. The three partners played a vital role not only in the design but also being fully engaged in the program delivery and evaluation. Also very closely involved in all stages was PA's learning development team.

HBS's input was led by its Business and Enterprise Architecture program director, a former European $\mathrm{CIO}$ - with commercial governance provided by the executive education client director. Since this program was a new and unique partnership development for HBS, direct sponsorship was sought from the HBS Dean as well as the relevant executive education and faculty heads. Academic rigour is provided by HBS together with an expert in organisation design from another business school, which demonstrates the non-parochial approach in obtaining the best capabilities.

The PA partners wanted the program to provide both IT and business experts with a deeper understanding of business and the professional use of technology, rather than concentrating on specific practices or technologies. The finished program has a 
strong practical focus underpinned by innovative, proven concepts. PA put highly experienced consultants forward for the program to ensure they both contribute to, and benefit from, the interactive delivery.

To make the program even more relevant and engaging, a selected PA client takes a key role in the final stage of the program which requires considerable stakeholder engagement to meet program objectives while understanding and responding to client needs - and at the same time enhancing the client relationship. This is a particularly innovative part of the program since each cohort engages with a different client.

Overall, the program approach aligns well to the Berggren \& Soderlund (2011) research advice on how to integrate theory and practice in management education program. This includes the following recommended tactics (which in this case were achieved through a comprehensive program approach):

- combine academic rigour with professional relevance (achieved via partnership design and assessment),

- emphasise both context and social learning (achieved via intensive workshop agenda),

- deliver innovative design and practices (achieved by planning joint HBS and PA sessions),

- connect reflection and action (achieved through organisation and business school assignments).

\subsection{Program Outputs and Outcomes}

The course runs for nine months in three distinct stages. The first self-study stage uses a HBS-developed Study Guide that incorporates an extensive set of sources, culminating in an exam. Individuals then participate in a five-day on-site module at Henley. The core thread of this is provided by a business design framework that links to elements including organisation design, architectural models and industry case studies. This module is assessed through a HBS-developed business design case study. The final stage encompasses a three-day course at HBS where a live PA client situation is outlined and the teams develop a design to meet the client need. Afterwards, the participants are asked to develop an architectural review of a real client situation. Successful completion of all three stages leads to a certificate in Business Design signed by both HBS and PA sponsors.

The program is a rounded and practical one, Experienced PA tutors provide professional and industry insights. Clients and guest speakers share practical experiences and case studies are derived from actual assignments. PA's commitment to the program is shown by the number of participating senior leaders. The program content has evolved to ensure that it remains up to date and relevant. The Head of PA Business Design comments, 'the BD program has really driven the building of world-class capability which benefits our clients and our people'. 
The PA co-author of this paper (Director in BD) reflected on the outcomes in relation to the original targets. 'PA has seen several advantages. Participants gain a holistic understanding of business design, supported by an innovative framework, and enhance their international PA networks. Both individually and collectively, they increasingly contribute to enhancing client business operating models. This compelling story and benefits for clients have translated into more and larger business design assignments for $P A^{\prime}$.

Overall the outputs and outcomes have met or exceeded expectations justifying the large investment made by PA in this key development program.

\section{CONCLUSIONS}

We conclude by examining the success factors, organizational lessons learned and the implications for future research.

\subsection{Program Success Factors}

We have highlighted the significance of partnership and this was dependent on a high degree of capability in both partners. PA had established successful practices in business and IT as well as a strong training function. HBS had similar subject strengths and had experience of program partnership development nationally and internationally. PA and HBS were willing to start the program with a goal rather than an immovable plan for future cohorts. Hence the parties were able to quickly move forward on the setup and design of the program.

Adopting and managing an evolutionary approach was a key success factor. In contrast to other initiatives, PA was willing to embark on the program without either a fixed consulting methodology or educational design. This was due to aligned leadership across both consulting partners and training management. It was then vital to seek an educational partner that could adopt and deliver a similar evolutionary approach, which educational institutions are not always noted for. The history and culture of HBS in working flexibly with executives was a key factor in making this happen.

Also critical was the joint governance of the program by HBS and PA. Setting up a clear and aligned governance structure provided a firm foundation. Inevitably in such a complex multi-year program, changes in leadership and context take place. Particularly for the early cohorts, HBS and PA held regular planning and program daily reviews with the aim of dealing with issues before they could become significant obstacles.

The multi-faceted design of the program worked well with a consistent program format and fine-tuning of the content. Different assessment methods supported the progressive capability development from knowledge test to business school case assignment to organization case evaluation. Assessing and achieving high business and program outcomes maintained the strong motivation in PA. 
The case highlights the importance of shared objectives and cross-functional alignment within and between PA and HBS. This does not mean compromising. As indicated by Lorange (2005) success can only be achieved by a continued attention given to the needs of all the stakeholders. Only through firstly aligning within each of the organizations was it possible to work together to evolve a multi-year, multi-cohort program that was truly transformational for both the individual and the organization (Kets de Vries et al, 2007).

Overall it can be seen that the program success was clearly predicated on PA and HBS bringing similar and diverse capabilities to an effective partnership in the leadership, design, delivery and evaluation of the program.

\subsection{Organizational Lessons Learned}

During this program journey, PA learned three key lessons at an organizational level. Firstly, focus on people development first, then methodology. PA found that this allowed them to build a methodology based on deeper insight than if they had embarked on this activity first, and then aimed to train and develop consultants in this approach. Secondly select a framework that complements, rather than is over prescriptive, to create a shared language. PA has many experts in different business and IT related discipline. The value came from joining these up, allowing consultants to have broader and richer insights, extending rather than replacing. Thirdly, what clients seek to buy is architectural insight. The methodology provides a way of generating architectural insight into sector or client specific problems, Engaging the market on these, rather than the quality of our methodology has been a more successful approach, and one that practitioners in architectural disciplines could learn from.

HBS in turn learned that it did not need to direct every aspect of the program in order to achieve success - providing as in this case the customer partner has the capability and motivation to make the collaboration, design and delivery work.

\subsection{Future research}

The authors acknowledge the limitations of a single case study and recommend further longitudinal research to assess whether the program success factors have wider transferability, both for research and education purposes. 


\section{REFERENCES:}

1. Berggren C, and Soderlund J (2011), "Management Education for Practicing Managers: Combining Academic Rigor With Personal Change and Organizational Action", Journal of Management Education, vol. 35 no. 3 pp. 377-405

2. Bernon M and Mena C (2013) The Evolution of Customized Executive Education in Supply Chain Management. Supply Chain Management: An International Journal vol. 18 no. 4, pp. 440-454, 2013

3. Kets de Vries M F R, and Korotov K (2007), "Creating transformation executive education programs", Academy of Management, Learning \& Development, vol. 6 no. 3, pp. 375-387

4. Lorange P (2005), “Strategy means choice: also for today's business school”, Journal of Management Development, vol. 24 no. 9, pp. 783-790, 2005

5. Vo H V, Chae B, and Olson D L (2006), "Integrating systems thinking into IS education", Systems Research and Behavioral Science, vol. 23, no. 1, pp 107-121

6. Wiita N and Leonard O (2017) How the Most Successful Teams Bridge the Strategy-Execution Gap. Harvard Business Review, November 2017 


\title{
OBRAZOVANJE U PODRUČJU DIZAJNIRANJA POSLOVANJA: STUDIJE SLUČAJA*
}

\author{
Sharm Manwani ${ }^{3}$ \& Mark Lancelott ${ }^{4}$
}

\section{Sažetak}

Akademski i profesionalni istraživači prepoznali su postojanje velikih izazova u operativnoj provedbi poslovne strategije. Ključni alat za rješavanje tih izazova je dizajniranje poslovanja, kako razvojnih (start-up) tvrtki, tako i velikih poduzeća koja teže inovacijama kako bi razvila nove poslovne i operativne modele. Veliki nerazmjer između strategije i provedbe navodi na zaključak kako postoji potreba za istovremeno rigoroznim i relevantnim obrazovanjem u području upravljanja. Akademske teorije ključne su, ali potrebno ih je udružiti s praktičnim rukovodnim uvidima.

Istraživanja pokazuju kako se visoke poslovne škole suočavaju sa značajnim strateškim izazovima prilikom provedbe obrazovnih programa koji se bave upravljanjem. Razlikuju se načela pedagoškog pristupa i razvoja programa za obuku profesionalaca $i$ menadžera siskustvom od pristupa studentima bez prethodnog iskustva. Postoji potreba za obrazovanjem koje se temelji na potražnji sadržaja, posebice u obrazovanju po mjeri, a ipak je potrebno očuvati akademsku čestitost kako bi se sačuvala vjerodostojnost. U tome je sastoji ključna prilika za poslovne škole, posebno ukoliko one mogu surađivati sorganizacijama koje pokušavaju poboljšati svoju sposobnost dizajniranja poslovanja.

Danas postoji malo objavljenih primjera uspješnih edukacijskih programa napravljenih po mjeri koji se bave dizajniranjem poslovanja. Ovaj rad daje longitudinalni prikaz jednog takvog programa koji se odvijao tijekom više od 5 godina, a uključivao je višse od 10 kohorti od više od 250 partnera $i$ viših konzultanata iz međunarodne konzultantske tvrtke koja se bavi inovacijama i transformacijom. Studija slučaja istražuje početak, osmišljavanje, provedbu i rezultate programa iz perspektive klijenta i poslovne škole koja je izvodila program.

Isporučeni program doveo je do uspješnih rezultata kako za konzultantsku tvrtku, tako i za njezine klijente. Ti se rezultati temelje na čvrstom partnerstvu između organizacije i poslovne škole koja je posljedica prilagodbe tijekom programa. Izrađeni su uvidi $i$ preporuke koji se odnose na vodstvo, dizajn i evaluaciju programa, pošto te komponente prema mišljenju autora imaju širu mogućnost prijenosa u istraživačke i obrazovne svrhe.

Ključne riječi: poslovna strategija, operativno izvršenje, poslovni dizajn, obrazovanje menadžmenta.

JEL klasifikacija: M12, N3

Rad je prezentiran na 3. Međunarodnoj konferenciji „Business \& Entrepreneurial Economics -BEE2018” koja je održana u Šibeniku od 30. svibnja do 2. juna 2018 (www.bee-conference.com)

3 Prof. dr. sc. Sharm Manwani, profesor, Henley Business School, University of Reading, Velika Britanija, E-mail: sharm.manwani@henley.ac.uk

4 Mark Lancelott, PA Consulting Group, Velika Britanija, E-mail: mark.lancelott@paconsulting.com 